\title{
Analytic Review on Theory of Living Hadith
}

\author{
Nawir Yuslem ${ }^{1}$, Sulidar ${ }^{2}$, Ahmad Faisal ${ }^{3}$ \\ ${ }^{1,2,3}$ Universitas Islam Negeri Sumatera Utara, Indonesia \\ raudatuzahra2010@gmail.com
}

\begin{abstract}
This study aims to review the theory of living hadith. Every time there must be a variety of science, art and views. Every pious at the present time the birth of a number of thoughts, schools of thought, views and knowledge in various sharia magazines, history, politics, economics, social and others. The majority of these sciences are sourced from non-Muslims, and do not rely on religious scales. The theory of living hadith is now open, because there are no restrictions, no conditions for commentators or syārih al-șadīṣ. Any interpretation by anyone is considered valid. The interpreter in this case is free to anyone without the conditions of the interpreter and without signs, including all verses and Hadith, including verses and traditions about faith and worship. This view, value-free and contextual without limits will exceed the value of faith.
\end{abstract}

Keywords

time dimension; faith; living hadith

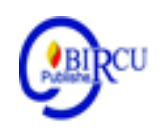

\section{Introduction}

Al-Quran contains matters relating to faith, sciences, regulations that regulate the behavior and procedures for human life. Al-Quran is also an inspiration for morals and life. Three-quarters of the contents of the Qur'an in general contain information and explanations about faith, good deeds and bad deeds, rewards for those who believe and do good deeds, threats for those who do not believe in the truth and who do bad deeds, history from previous and exemplary peoples and ibrah which can be taken from their experiences. (Nuraini, 2020)

Syarah Hadith is one of the important branches in the science of hadith. The definition of this knowledge is categorized as rarely due to the lack of writing views about this science. Although the traditions of the hadith are in the hundreds, one of them does not include a discussion around the methodology of the shariah. In fact, the study of the field of application has not been seen in this science, it is not yet clear what its types, research methods, methods and manners as well as the science of sharia are not mentioned as one type of hadith in various muștalah books. This was hinted by Fatḥ ad-Din Bayānūnī, by saying, "But strangely, this hadith syariah is not known as an independent type or a type of hadith science in various muștalah books, both old and latest. This may be due to feeling sufficient with Gharì $b$ al-siadìs, because the knowledge of gharīb al-sadīs helps understanding the hadith.

The scholars had a variety of methods in interpreting or understanding the hadith originating from as-Sunnah an-Nabawiyyah. They took part and agreed in the same goal, namely the effort to achieve in knowing the intentions of the Prophet's Hadith in accordance with their abilities as human beings. There are four syarh al-hadìs methods and patterns (in explaining the meaning, meaning, content or message of the hadith), namely: the tahlinli method, ijmālì, muqārin, and the mauḍ̄ 'i method.

Every time there must be a variety of science, art and views. Every pious at the present time the birth of a number of thoughts, schools of thought, views and knowledge in various sharia magazines, history, politics, economics, social and others. The majority of these sciences are sourced from non-Muslims, and do not rely on religious scales. Even in certain aspects its 
development can be said to have transcended borders, such as attitudes to adopt Western thoughts whose concepts are without conditions of interpretation, without signs and without limits and abandon the theories of Hadith studies which have been built by scholars for centuries -century. Because contextual understanding, hermeneutics, living hadith, and theories about the research on the authenticity of Hadith adopted by some Islamic intellectuals will lead to the completion of the Hadith. So with that the reviewers of the Hadith must make efforts for supervision and rectification so that Islam does not lose one source of its teachings, namely the Hadith. This is what demands us to study various thoughts and knowledge and discuss them within the scope of the Qur'an and the Sunnah of the Holy Prophet. Muslims really need to know the views of the Qur'an and Hadith on an ongoing basis to give birth to a variety of new discoveries and views, so as to clarify the valid Islamic manhaj which covers various scientific fields which can then be utilized and applied in the reality of the lives of Muslims today.

For example, shärihu al-hadīis is a person who deals in the field of syarh al-sidìis, such as Imām Aḥmad ibn 'Alī ibn Hajar al-'Asqalānī (773-852 H), he is thanking traditions in the book Șahīh al-Bukhārī by the name of the so-called al-Bukhari Fath al-Bārī bisyarḥ Sahīh alBukhārī. Likewise, the book of syariah Șahīh al-Bukhārī, 'Umdatu al-Qārī by Badr ad-Din Maīmūd ibn Aḥmad al-'Ain̄̄ al-Hanafī.

Throughout the discussion of living hadith that has been discussed previously, is there any discussion about the terms of the tradition of the hadith (syārihu al-siadìs), while the study of living hadith is aimed at making people smart in presenting the tradition with the method of living hadith. Because the living hadith is a reception (reception, reaction, response or response) to a group of Muslim communities that originate from a Hadith. The situation is both in a personal form (personal) and that occurs in the life of the community. A person who wishes to conduct a study of living hadith should have the characteristics and conditions of the hadith and their manners.

So far based on journals, articles and book readings have never talked about this. Therefore it is necessary to talk about the conditions of people who study living hadith, because it is very irrational for someone who does not understand Arabic to become shärihu al$\dot{s} a d \bar{i} \dot{s}$, or to become a commentator of the Qur'an.

\section{Theoretical Framework}

Before explaining the etiquette of the hadith pilgrimage it is explained first about the characteristics and conditions for the hadith (shärih al-hadìis).

\subsection{Characteristics and Conditions for Shärih al-Hadīs}

\section{a. Characteristics of Hadith Pilgrimage}

A devotee must have certain characteristics, so that he can be called an expert and expert in the field of shari'ah traditions. As for some of the properties or characteristics are as follows;

\section{1) Have sincere intentions}

Intention is the initial foundation before doing work. All actions arising from a believer are considered true if accompanied by intention. Therefore, for the hadith observers must be sincere and rectification intentions. In one of his traditions, Rasulullah SAW. Said:

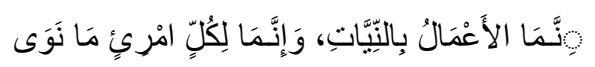


[Setiap perbuatan tergantung niat, dan setiap orang tergantung pada niat yang dimilikinya.]

The purpose of the word an-niyyāt is something that is used as a goal or niyyah is a goal that someone leads to that place.

\section{2) Seriousness in Studying Knowledge}

Studying knowledge is the noblest deed done by humans throughout his life. Because of this, God commands humans to always ask for additional knowledge, as He said,

$$
\text { وَقْلْ رَبَِّ زِدْنِي عِلْمًا. }
$$

[And say: O my Lord, add to me knowledge]. Q.S. Țāha / 16: 114

This is quite an explanation of the position of science that is very noble. Imam al-Qurtubi said, "If there is something nobler than knowledge, then Allah will surely command His Prophet to make a request.

Be patient and be patient

Doing the act of writing knowledge, looking for solutions and education is an act that requires time and patience at the same time. Allah SWT. Say in the Qur'an,

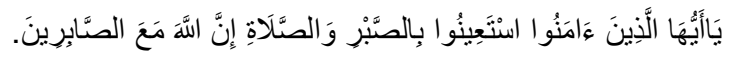

[O you, who believe, make patience and prayer as your help, verily Allah Almighty. along with people who are patient]. Q. al-Baqarah: 153

\section{3) Courage}

As for what is meant by courage here is not in dealing with various dangerous conditions, but courage to think, namely courage in being responsible in giving birth to thought, accuracy in truth, informing what is obtained correctly and clearly even though his opinion is contrary to a custom, school or a groups, not skewed by the wind, just to get the pleasure of a leader, a group or a friend. For example, as happened in the reign of the Caliph al-Ma'mūn. During his reign, the power of the Răfiḍah and Mu'tazilah was very strong. The caliph invited Muslims to say the Qur'an is a creature. Finally, the scholars got an exam, one of which was Imam Ahmad. This is because they refute the Caliph's statement and reject the Caliph's invitation. According to them the caliph had revealed something heretical lafaz, because he claimed that the Qur'an was a creature. Imam Aḥmad said;

\section{4) Manners}

Adab towards the Messenger of Allah. is one of the things that every Muslim needs at all times and places. Allah SWT. said,

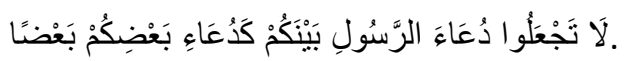

[Do not make the Apostle's calling among you like your partly to another (other) part]. Q.S. an-Nūr / 18: 63 Allah SWT. said,

Civilization, fadilat, charity and morals are some of the pillars in interacting with assunnah an-nabawiyyah, and the Prophet. Considered to be a teacher who delivered the Shari'a which delivered it from Allah. Therefore, we must not recite his words except 
those which are in accordance with what the Salaf have done, in accordance with the Shari'a and common sense.

\section{5) Al-Maudū ‘iyyah (Objectivity)}

The definition of al-Mauḍu' 'iyyah is neutrality and impartiality when expressing opinions and discussing various discussion themes. A good researcher is a researcher who sees an essence with an objective view, only to make use of benefits both personal and related to the school, group or state.

Consistency in objectivity makes a person according to the tradition of following the hadith, not the hadith that is made must follow to support various opinions that fit with it. Hadith is an Imam not a congregation. Hadith is a clue not a clue. Hadith is a judge not a convicted one. On the other hand, a pious person who puts forward objectivity in his shari'ah makes him an objective and does not take sides with one opinion of the shari'ah scholars and ignores the other unless there is a clear argument or qarinah.

\subsection{Criteria and Conditions for Hadith Pilgrimage}

Throughout the discussion of living hadith, that study of living hadith is aimed at making people smart in presenting the tradition with the method of living hadith. A person who wishes to conduct a study of living hadith should have the characteristics and conditions of the hadith and their manners.

As for what the writer means by the criteria and conditions for the hadith pilgrimage, there are a number of cases that must be fulfilled so as to make someone truly worthy to be involved in the fields of hadith, understanding the meaning of hadith and drawing conclusions from the instructions of the prophetic tradition. Here are four conditions, namely:

\section{a) Mastering Arabic and Various Rules}

The Qur'an was revealed in Arabic with the language al-mubin, which means language that can explain. Allah SWT. It says:

[The Qur'an descended with Arabic which is mubin (clear)]. Q.S. asy-Syu'arā '/ 19: 195 Ibn Faris (d. 395) one of the language scholars stated: when Allah Almighty. Choose Arabic to explain (His word), showing that other languages, abilities and levels are below Arabic.

\section{b) Study of the Sciences, Rule and Hadith of the Hadith}

For a hadith participant must master everything related to the sciences of traditions, a variety of general rules that are used as guidelines and restrictions in making the traditions of tradition. This is a safe method for entering into true and perfect sharia. Such as knowledge of various rules related to takhrij hadith, the study of sanad, the validity-daif assessment, the understanding of mukhtalif and abstruse of hadith, nasih-mansukh, words that are gharīb (foreign), asbāb al-wurūd and other rules put forward by ulama in the science of hadith, nasih-mansukh, words that are gharīb (foreign), asbāb al-wurūd and other rules put forward by ulama in the science of hadith. -You hadith.

\section{c) Academic Experience on Various Problems That Become Objects of Hadith Shari'a}

A researcher must also master the material or discussion that will be examined in the perspective of his hadith, so that he is able to be professional and objective in his study. 


\section{d) Pilgrims Must Know the Scientific Discussion Method}

The method of scientific discussion is the method or method adopted by a scientific researcher in research to find the scientific nature in various branches of science. Scientific discussion is research that is specialist in the title of the discussion that is determined in accordance with certain methods and rules. In the implementation of systematic scientific discussion of any kind, theoretical or practical, it is the highest scientific activity with no end limit.

\section{Discussion}

\subsection{Adab Pilgrimage of Hadith}

Adab etymologically means $m \bar{a}$ yata'addabu bihi al-'adīb min an-nās, which is something done by a civilized human being. Named manners because he is the one who educates and directs towards commendable behavior and prevents himself from being blamed. Adab also means self-training with proper teaching and self-correction. The result of etiquette is to improve someone who occupies himself with the hadith tradition and to implement that etiquette. Among others are:

a) Ask Allah for help

Allah SWT has taught us to ask for help from Him, even obliging us to always repeat it. Allah SWT says in the Qur'an,

[Only You are worshiped, and only We ask for help]. QS. al-Fatima / 1: 5

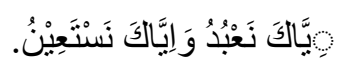
From Abu Hurairah, said: The Messenger of Allah. said,

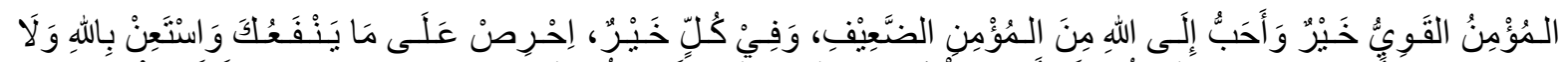

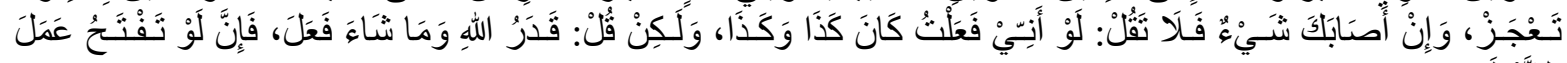
الثَّبَّنَان.

[Strong believers are better and more loved by Allah Almighty. than the weak believer; and in both of them there is goodness. Be earnest to get what is beneficial to you and ask Allah for help. (In all your business) and do not ever feel weak. When you are struck with disaster, do not say: If I did so, surely it would not be this way and that way, but say, This has been destined by God Almighty, and God Almighty. do whatever He wants, because the words if will open (the door to) the act of devil].

\section{b) Be Serious In Resolving Sharia}

For a shy, his obligation is to fulfill all shariah rights and not just to make sharia. However, he must issue a variety of sincerity according to his ability to apply the methods he wants to follow in carrying out the activities of the hadith. The scribe mentioned many specific methods that he wanted to hold in his book and applied them at the beginning of his book. Therefore, something that is demanded from a pilgrim is ihsan in his work. Alquran has given good news to those who acted muhsin in their deeds in order to get merit.

Allah says,

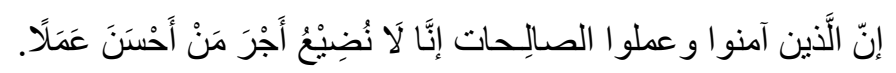

[Indeed, those who believe and do good deeds, surely We will not waste the rewards of those who practice (his) good practice]. QS. al-Kahfi / 15: 30 


\section{c) Not Commenting When Conducting Sharia and Explaining Its Meanings Without Scientific Knowledge}

A hadyarah scholar may not be involved in the hadith's shari'ah activities and the explanation of their various meanings without any scientific knowledge possessed. He even had to refer to various expert opinions and ask them. Allah says in the Qur'an,

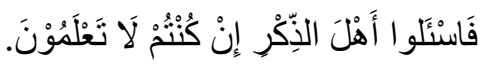

[Then ask someone who has knowledge if you don't know]. Q.S. an-Nahl / 14: 43

Imam Ahmad was once asked about the interpretation of one of the words gharīb in the hadith, then he was silent and then he said, "Ask the expert (words) gharīb, actually I do not like to talk about the words of the Prophet accompanied by conjecture, then I am also wrong." When Syu'bah was asked about one of the lafaz of hadith, he said, "Try asking alAșma'ำ, because he knows more about this from us."

\section{d) Not Making Sure What the Pilgrims Found Was Really the Mean of the Holy Prophet}

One of the manners that must be applied by a pilgrim is to investigate the explanation of the meanings of the hadiths, especially those who have various tendencies and do not ensure that what he finds in the Shari'ah is really the intention of the Holy Prophet. performing the hadith syariah is not an easy matter. For the hadith experts, ignorance of the traditions of the hadith is a despicable act, it will be difficult for those who want to explore it, it is worth investigating by recording and explaining the traditions.

\section{e) Trying to Release Islam from Various Accusations}

Sometimes a pious person during a collection, the endorsement of hadith faces various accusations. Under these conditions, he must defend and defend against various accusations (against the teachings) as best he can, as has been done by Salaf imams such as Imam Ibn Qutaibah al-Dīnawarī in his book "Ta'wīl Mukhtalif al-ṡadī̇s" and others.

\section{f) Maintaining Scientific Trust}

One of the most important etiquettes that must be possessed by a Hadith scholar is to have a scientific mandate and this scientific mandate comes in several forms, including:

- Trust in the restriction of thought and various statements to the person who conveys it and gives the rights of everyone who has rights.

Imam as-Suyūṭ̂̄ said, "One form of blessing and scientific gratitude is to rely on it (the knowledge) to the person who conveys it." A shy person is also obliged to hint to the original nas if he does tașhị 1 or ta'dīl and is not satisfied with the correct explanation in his ijtihad, because it may be that the original nas is the right one, but he is wrong in giving a syllable, because his understanding is not in accordance with his form.

- Counseling each other in Science.

Sourced from Ibn Abbas, that the Messenger of Allah. once said,

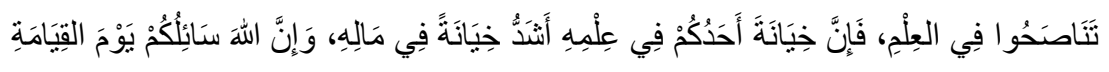


[You should give advice to each other about knowledge. Indeed, the betrayal of one of you to his knowledge is greater than his betrayal of his property. And surely Allah will hold you responsible on the Day of Resurrection].

- Not Hiding Science.

Allah SWT. say in the Qur'an,

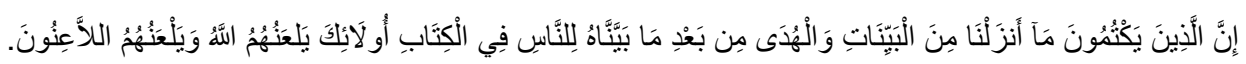

[Indeed those who conceal what We have sent down are in the form of (clear) statements and instructions, after We explained it to humans in al-Kitab, they were cured by Allah and curbed (also) by all (sentient beings) who could do so. ] QS. Al-Baqarah / 1: 159

Sourced from Abu Hurairah, Rasulullah SAW once said,

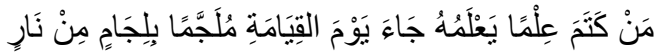

[Whoever hides the knowledge that he knows, then that person on the Day of Judgment comes shackled with the chains of hellfire].

\subsection{Activities and Limitations of Living Hadith}

A believer believes that the Hadith is an operational explanation of the Qur'an. Alquran whose verses are mujmal, absolutely deserve an explanation. The most valid explanation of the Qur'an is the Hadith. The Qur'an repeatedly emphasizes that a believer remains guided by the explanation of the Prophet's Hadith. The existence of the Prophet's Hadith in history is not all the time in written form, but in the form of memorizing delivered in a chain. Therefore, the scholars of hadith try hard to keep the traditions well maintained. At first the scholars focused solely on the study of sanad, the narrators of the hadith (ruwwāh). After that, there was the need to examine the text of the hadith and its implementation in the daily lives of Muslims.

Such traditions are very popular in the community. The hadith must not be banned or rejected because of the living hadith. From the standpoint of the theory of living hadith is true because the practice is inherent in the community that is believed to originate from the Hadith. But apparently, the hadith is not found in the books that are read as references for the hadith. Namely the books that mention matan hadith complete with its sanad, such as the book of Sahịh al-Bukhārī, that's where the weaknesses of living hadith. Therefore there need to be signs or limitations in living hadith.

The theory of living hadith is now open, because there are no restrictions, no conditions for commentators or syārih al-sadīs. Any interpretation by anyone is considered valid. The interpreter in this case is free to anyone without the conditions of the interpreter and without signs, including all verses and Hadith, including verses and traditions about faith and worship. This view, value-free and contextual without limits will exceed the value of faith.

In essence, the dimensions of time and space are related to one another and are not separate. Because the human condition that was felt by the Prophet during the time of the Prophethood was the Arabs who were residents of the Arabian Peninsula, so that both dimensions were experienced by the Prophet and he also interacted with him for 23 years.

Based on a number of Hadiths and asar collected to discuss which limits are allowed to live a hadith, as well as the influence of Hadith and $A \dot{s} a r$ in the dimensions of time and space, the author finds several conclusions as follows: 
1) The scope and limitations of living hadith (Sunna which is eternal) because it has no effect on both dimensions $(a \dot{s}-\dot{s} a w \bar{a} b i t)$ :

a. The scope of constant creeds (static) does not change and last forever. The legal form does not change except under compulsion.

b. Principles of worship such as the obligation of Taharah, prayer, fasting Hajj and zakat. Then the law does not change and the numbers and the way they are carried out, except those related to the way they were carried out when they were senile.

c. General principles of Islam in matters of muamalah, law, justice and others. Like the basis of deliberation. The basics of halal trading, syirkah, leasing, loans, justice and equality. The basics are forbidden to eat wealth in a vanity way such as usury, risywah, stealing, looting and wrongdoing. The basics of halal marriage, divorce, khulu ', iddah (menstruation). Likewise the basics are forbidden to deal with the opposite sex that is not prescribed as adultery, liwat, sihaq (lesbi). The basics of law and qișās, and so on.

d. Morals and values. Like the beauty of honesty, trustworthy, 'iffah, courage, courtesy, and others of commendable morals. Also such as ugliness, betrayal, danā'ah (dirty), cowardly, stingy and others from the despicable morals. All this does not change the beauty and the ugliness that is affected by time and space, except in circumstances that allow lying to benefit.

e. Divine Sunna. Allah says in the Qur'an,

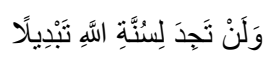

[and you will never find a change in the sunnah of Allah]. Q.S. al-Aḥzāb / 22: 62, Q.S. al-Fath / 26: 23

Allah also said,

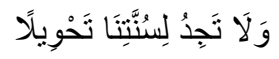

[and you will find no change in our provision].

Q.S. al-Isra '/ 17: 77

f. Various problems specific to the Prophet such as the obligation to pray at night, the obligation to pray duha, the necessity of fasting wișâl, and not marrying his daughter during life, and others.

These various things do not affect both dimensions, and this shows that the problem belongs to the category of $\dot{s} a w a \bar{a} b i t$ which does not change. There is no influence of these two dimensions on the situation except in certain circumstances (emergency). Because the provisions of these cases are a form of guarding the Islamic community from damage and collapse as well as part of the practice of the continuity of the Shari'a and its development is based on a variety of sturdy machinery that cannot be broken the passions and changes in society. This $\dot{S} a w a \bar{a} b i t$ reinforces Islamic sharia as something that is clean and clean in all places and times, in various environments and societies, as well as in every country, city and village.

2.) The scope and boundaries of the living hadith (Sunna which follows the circumstances) or areas that can affect both dimensions (mutaghayyirät)

a. Related to the hadith related to branching out the basis of worship or the application of the basics.

b. In connection with the prophet's orders addressed to the rulers of the country and the leader of the troops, the selection of delegates, the administration of the troops, the design of war strategies, the distribution of settlement and urban boundaries, the 
separation of the treasury of treasures in various benefits, the conclusion of the agreement, the restriction of $t a^{\prime} z \bar{v} r$ and its implementation, the method of applying hudud and $t a{ }^{\prime} z \bar{v} r$, limitation of time and circumstances and other restrictions.

c. Relating to the methods of human experimentation, customs and habits. Like some of those contained in medical traditions and other worldly matters.

d. Prophet's customary deeds, recommended commands such as eating, drinking, walking, sleeping, movement and others.

The following are a few examples of the standardization of the influence of the two dimensions on the area of influence they can influence:

\section{Aḍ-Ḍarūrāt asy-Syar'iyyah and State of Exceptions}

Emergency is a condition that befell humans in the form of severe dangers and difficulties, where it is feared that danger or illness will occur to themselves or members of the body, or honor, property and others that can be ascertained and allowed when doing illicit acts or leaving an obligation or postpone it from time to prevent danger that is in strong suspicion, according to the limits set by sharia.

The basis of aḍ-ḍarūrāt asy-syar'iyyah comes from the Qur'an ,

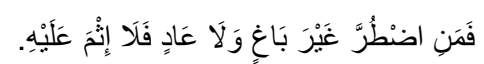

[But whoever is forced (to eat) while he does not want to and does not (also) exceed the limits, then there is no sin for him]. Q.S. al-Baqarah / 2: 173

Another basis is a fiqh rule that reads,

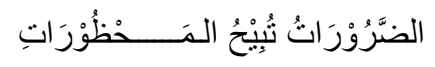

[Emergency conditions allow (violate) prohibited acts].

In the Sunnah it is explained that the Messenger of Allah punishes by the principles of fiqh, he justifies something that was previously forbidden, gives some exceptions to a problem in accordance with this rule, and gives some specialties from something that is common, binds to some that are absolute and gives relief to some circumstances that deserve relief. These realities are not on an emergency level. All of these conditions do not mean one level from the durat. Some of them are in the ad-darūrāt (primary interest) category, it can also be part of the alal-häjiyyāt (secondary interest, urgent interest), and several other things fall into the attahsiniyyt category (complementary interest). This can be seen in the following examples:

\section{a. Something that is associated with some changing nature}

The provisions of sharia have made clear through its generality and continuity that the greatest aim is to link various diverse sharia laws with diverse circumstances and characteristics. Changes in state and nature are divine sunna on every being. Therefore this shows the change in law with the changes in the nature associated with it is a necessity. As for some examples of this from the sunnah are as follows;

Among the reluctance of the Prophet to provide a price determination. Narrated from Anas, that people said to him, "O Messenger of God, the price of goods has jumped up, then set the price for us!" Then he answered 


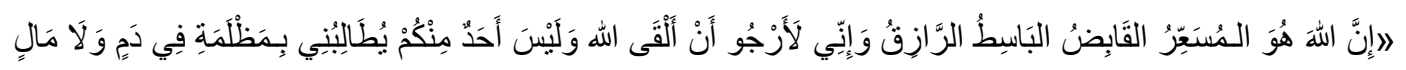

[Verily, it is Allah Who determines the price, the One who grasps and the One who spreads, and the Giver of sustenance. And truly I hope to meet with Allah while none of you will sue me for wrongdoing in the matter of blood, and wealth].

The context of the hadith shows his reluctance to set prices related to changing nature. Where they are in a natural spike as a result of the law of availability and demand, or due to the lack or quantity of goods and not due to merchant permanence.

\section{b. Linkages with changing benefits}

Islamic Sharia is very concerned about benefits in various forms of distribution. Even as the ash-Shafi'i points out, this Shari'a was revealed to bring benefit to His servants. The various taklif laws are all related to preventing mafsadah or bringing benefit or realizing both (preventing mafsadah and attracting benefit). All who enter and are in it is the purpose of the coming of this Shari'a. Maslahat in this world in its changing form and many cannot be counted. Jumhur fukaha (Islamic jurists) agreed that this benefit was recognized in the stipulation of fiqh law as long as it was not accompanied by lust lust, did not contradict religious texts and did not deviate from its various objectives.

\section{c. Something That Is Built Based on Customs and Habits Can Change}

There is no doubt the song, that habit and customs are one part of power. The Islamic Shari'a has recognized this power and preserved its various laws. In the Sunna, we can find laws that changed after the time of the Holy Prophet. Because it is based on customs and habits, so it can be said that customs and habits can change the law. The example of this from the sunnah is as follows;

1) Prohibition of $n a$ ' $y u$ (announcing) the death of a person. Among the related traditions are:

a) Sourced from Abdullah from the Prophet. He said,

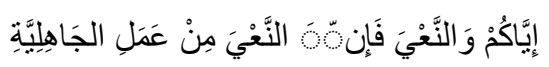

[Keep away from na'yu (announcing), because $n a^{\prime} y u$ (announcing someone's death) is a practice of ignorance].

b). Hadith originates from Hużaifah ibn al-Yamān,

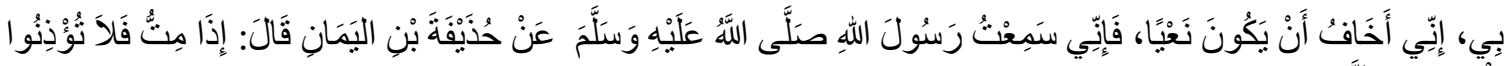

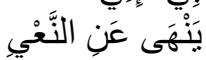

[If I die, then you don't hurt me. I was worried about being na 'yu (announcing), and I had heard the Prophet forbid na'yu (announcing)].

c) Anas ibn Mālik's Hadith that he said:

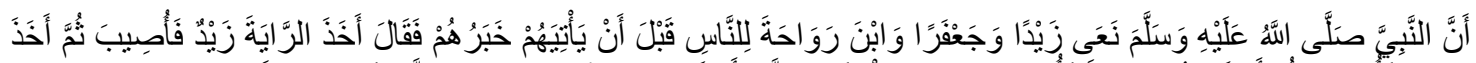

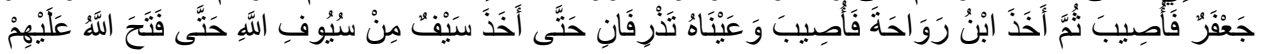

[That the Messenger of Allah. announced the deaths of Zaid and Ja'far and Abdullah ibn Rawāhah raḍiyallāhu 'anhum to the companions before news came to them about it. He said: "The flag was taken by Zaid, then he was killed, then the flag was taken by Ja'far, then he was killed, then subsequently the flag was taken by Abdullah ibn Rawāhah, then 
he was killed, while both eyes of the Prophet shed tears, until then the flag was taken by the sword from the swords of Allah (Khalid ibn al-Walid) until Allah gave them victory].

d) Hadith from the history of Abu Hurairah:

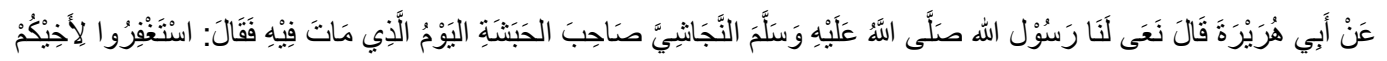

[Sourced from Abu Hurairah, he said, "The Messenger of Allah had done na yu (announced) an-Najasy a ruler of Habsyah when he died. He said, "Ask forgiveness for your brothers (this)."].

\section{d. The relationship between space and time can change the law}

In this case the existence of the relationship between space and time in change, for example are as follows:

His orders to cool off from the midday heat, as narrated by Abu Sa'īd al-Khudrī said,

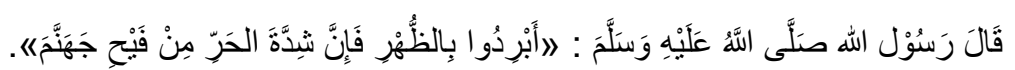

[The Messenger of Allah said: "Suspend the midday prayer until it is cold, because the scorching heat is part of the vapor of hellfire."].

Ibn Hajar said, "According to the cleric Jumhur, it is recommended to postpone the implementation of the noon prayer during the hot sun until it is slightly cold." It is narrated from ash-Shafi'i, that this applies in the Hijaz where the heat is very hot there. As for Madinah there is no mosque in it apart from the mosque of the Prophet. "

\section{e. Something from the Prophet in the form of sadd aż-żarāi' (closing the gap)}

The basis in the recognition of sadd a $\dot{z}$-zaräi 'a which can be the principle of legal change is to look at the results of actions. If the result or result is in the form of benefits (goodness), then it can be done in a size appropriate to the benefit. Likewise, if the effect or result is mafsadah (destruction), then it is not permissible in accordance with what is forbidden in the mafsadah it causes. Likewise, seeing the effect or effect here is not based on the purpose of the subject, but must be an effect and the result of the action.

The examples of this rule are present in Hadith and also Jurisprudence, including:

1) The Prophet's reluctance. kill hypocrites.

As is known by Abdullah ibn 'Ubay is a leader of hypocrites whose hypocrisy is very clear as the sun, especially after the revelation of the letter al-Munafiqun which opened evil intentions against Islam and Muslims. He said (as enshrined by God in His word),

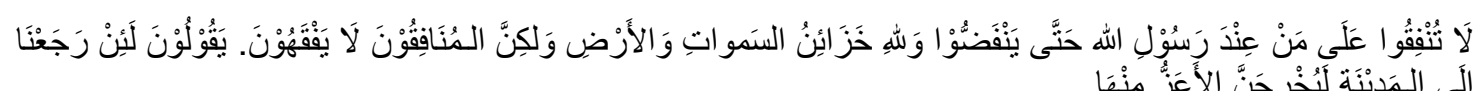

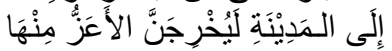

[They are those who say (to the Ansar): "Do not give alms to the people (Muhajirin) who are on the side of the Prophet so that they disperse (leaving the Messenger of Allah)." Though Allah belongs to the treasury of heaven and earth, but the hypocrites do not understand. They said: "Indeed, if we have returned to Medina, truly the strong will drive out the weak from him." Though the power is only for Allah, for His Messenger and for the believers, but the hypocrites do not know]. Q.S. al-Munafiqun / 28: 7-8 
This last statement is the first call of racism to glorify the natives and attribute disgrace to migrants. This is very much felt by the world in general, and Muslims in particular today even though there are many voices calling for human rights.

2) Another example of his prohibition on the construction of a mosque above a cemetery so that it does not become a gap to make the inhabitants of the tomb as idols worshiped. Sourced from Ayesha from the Prophet when he was ill before he died. Rasulullah SAW. said,

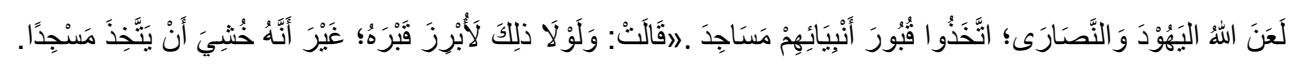

[Allah curse the Jews and Christians, because they make the graves of their Prophets as a mosque. Aisha said, "If it wasn't for fear (curse), surely his grave would be elevated (revealed), only it was feared it would become a mosque."].

3) Likewise, as stated previously, where he forbade cutting off the hands of the perpetrators of theft in a state of war, so as not to open the gap he approached the infidels, especially if he was an ordinary layman, and the enemy would feel satisfied and proud if (the perpetrators the thief to be punished)

\section{Conclusion}

It can be concluded that the tradition of the hadith is asking for help from Allah SWT, asking for help from Allah SWT, not making comments when making shariah and explaining their meanings without knowledge, not making sure what the finder found was really the Prophet's intention, trying to release Islam from various accusations, maintaining scientific mandate.

\section{References}

Abd ar-Raḥmān ibn Abī Bakr jalāl ad-Dīn as-Suyūṭị. (2003). Tadrīb ar-Rāwī fì Syarḥ Taqrīb an-Nawawī (Mamlakatu al-'Arabiyah as-Su'ūdiyyah: Dār al-'Āṣimah), juz II, h. 185

Abd al-Wahhāb Ibrāhīm Abū Sulaimān. (1986). Kitābatu al-Bahịs al-'Ilmī wa Maṣādir adDirāsāt al-Islāmiyyah (Jeddah: Dār asy-Syurūq), h. 21.

Abī al-Ḥusain Aḥmad ibn Fāris ibn Zakariyyah ar-Rāzī. (1993). aṣ-Ṣāḥibī fī Fiqh al-Lughah al'Arabiyyah wa Masā;iliha (Beirūt: Maktabah al-Ma'ārif), h. 44.

Al-'Asyrafī, asy-Syarh al-Mauḍ̄' ‘̄i, h. 107

Al-'Asyrafì, asy-Syarḥ al-Mauḍ̄'‘̄', h. 111.

Bukhārī, al-Jāmi u. (1907). bāb Kaifa Kāna Bad'u al-Waḥy ila Rasulillāh, no. 1, h. 1. AnNaisabūrī, Șahịị, h. 1056.

Departemen Agama RI., Al-Qur'an dan Terjemahnya (Riyadh: Darussalam, 2006), h. 444.

Fatḥ ad-Dīn Bayānūnī, Ahammiyyat asy-Syurūḥ wa Qawa'iduhu, Kitāb Mu'tamar Manāhij Tafsīr al-Qur'ān al-Karīm wa Syarḥ al-Ḥadīs asy-Syarīf (Buku, tidak diterbitkan), h. 951.

Ghāzī Husain 'Ināyah. (1983). Manāhij al-Baḥs (al-Iskandariyyah: Mu'assasah asy-Syabāb alJāmi'ah), h. 75.

Haifā' 'Abd al-'Azīz al-'Asyrafì, asy-Syarḥ al-Mauḍū'ī li al-Ḥadī̇̀ asy-Syarīf. (2012). (alQāhirah: Dār as-Salām), h. 57

Ibnu Manẓūr, Lisān al-‘Arab (al-Qāhirah: Dār al-Ḥadīì, 2003), Juz I, h. 100. 
Nuraini. (2020). The Potentials of Goodness and Badness in Humans on the Qur'an and Hadith. Budapest International Research and Critics Institute-Journal (BIRCI-Journal). P. 718728

Majma' al-Lughah al-'Arabiyyah, al-Mu'jam al-Waj̄̄z. (1994)(Miṣr: Wizāratu at-Tarbiyyah wa at-Talìm), h. 9.

Muḥammad ibn 'Abd ar-Raḥmān as-Sakhāwī asy-Syāfi‘̄i, Fatḥ al-Mughīs bi Syarḥ Alfiyati alHadīs. (2009). (ar-Riyāụ: Maktabah Dār al-Minhāj, 2005), Juz III, h. 422. Aḥmad ibn 'Alī Abū Bakr al-Khațīb al-Baghdādī, al-Kifāyah fì 'Ilmi ar-Riwāyah (Beirūt: Mu'asasah ar-Risālah), h. 282. 